\title{
(2) OPEN ACCESS \\ Sideroblastic anaemia in a patient with sickle cell disease
}

\author{
Nikitha Vobugari (D) ,' Mansi Chaturvedi, ${ }^{1}$ Ilana Miriam Schlam-Camhi, ${ }^{2,3}$ \\ Hedy Patricia Smith ${ }^{3}$
}

${ }^{1}$ Internal Medicine, MedStar Washington Hospital Center Washington, DC, USA ${ }^{2}$ Hematology/Oncology, Tufts Medical Center, Boston, Massachusetts, USA ${ }^{3}$ Hematology/Oncology, MedStar Washington Hospital Center, Washington, DC, USA

\section{Correspondence to} Dr Nikitha Vobugari; nikithavobugari@gmail.com

Accepted 6 January 2022
Check for updates

(c) BMJ Publishing Group Limited 2022. Re-use permitted under CC BY-NC. No commercial re-use. See rights and permissions. Published by BMJ.

\section{To cite: Vobugari $\mathrm{N}$}

Chaturvedi M,

Schlam-Camhi IM, et al. BMJ Case Rep 2022:15:e246623. doi:10.1136/bcr-2021-

246623

\section{SUMMARY}

Sideroblastic anaemia is a rare condition. We report a unique case of concomitant sideroblastic anaemia in a patient with sickle cell disease with long-standing blood transfusion history. Due to a low prevalence of sideroblastic anaemia, the diagnosis of sideroblastic anaemia is often difficult, especially when coexisting with common types of anaemia, including sickle cell disease. This case highlights the detrimental effects of anchoring bias. Rare causes of refractory anaemia should be considered in patients with haemoglobin disorders as the therapeutic approaches for these conditions are different. High suspicion on the part of the clinician and low threshold for workup of anaemia often aids in the diagnosis of coexisting conditions such as sideroblastic anaemia. Early diagnosis and treatment of sideroblastic anaemia improves patient outcomes and prevents longterm complications.

\section{BACKGROUND}

Sickle cell disease (SCD) is a hereditary haemoglobin disorder caused by a point mutation in the betaglobin gene found on the short arm of chromosome 11. This mutational change leads to the replacement of the hydrophilic amino acid glutamic acid with the hydrophobic amino acid valine, resulting in the production of a less soluble form of haemoglobin, known as sickle haemoglobin. ${ }^{1}$ SCD affects approximately 100000 Americans and is seen most frequently in individuals of African descent. ${ }^{2}$ SCD has been known to cause complications that include haemolytic anaemia, vaso-occlusive crises, chronic pain, multiorgan damage from tissue ischaemia or infarction, all of which have a major impact on morbidity, mortality and quality of life. ${ }^{3}$

Sideroblastic anaemias (SAs) are a heterogeneous group of erythropoietic disorders that can be congenital or acquired. ${ }^{4}$ SAs are rare, and data on incidence and prevalence rates are limited. ${ }^{56}$ SAs are caused by mutations in genes involved in hemesynthesis, iron-sulfur cluster biogenesis and mitochondrial or cytoplasmic enzyme metabolism. ${ }^{467}$ SAs can be non-syndromic or syndromic. Non-syndromic SA includes X-linked sideroblastic anaemia gene (XLSA) mutation, mitochondrial transporter SLC25A38 defects, mitochondrial heat shock protein 70 (HSPA9) defects, mitochondrial heat shock cognate protein 20 (HSCB) defects and glutaredoxin 5 deficiency, and erythropoietic protoporphyria. Syndromic SA comprises XLSA with ataxia (XLSA/A), SA with B cell immunodeficiency, periodic fevers and developmental delay
(SIFD), SA with myopathy and lactic acidosis (MLASA), Pearson marrow pancreas syndrome and thiamine responsive megaloblastic anaemia (TRMA). ${ }^{47}$ Congenital SA (CSA) is most commonly $\mathrm{X}$-linked and caused by missense mutations in the erythroid-specific d-aminolevulinate synthase gene ALAS2 (XLSA). The enzyme product of this gene is involved in the first step of heme biosynthesis. ${ }^{6}$ Autosomal recessive CSA (ARCSA) is the second most common hereditary SA, and is caused by mutations in various mitochondrial genes including SLC1125A38, a mitochondrial carrier/transport protein. ${ }^{4}$ Acquired SA includes clonal disorders such as myelodysplastic syndromes (MDS) and myeloproliferative neoplasms $(\mathrm{MPN})^{8}$; while others are non-clonal and related to excessive alcohol use, lead toxicity, copper deficiency, pyridoxine deficiency, isoniazid therapy. ${ }^{49}$

Initial workup for SA includes complete blood count with white cell count (WCC) differential, iron studies, serum ferritin, reticulocyte count and lactate dehydrogenase $(\mathrm{LDH})$. Bone marrow biopsy showing erythroblasts with iron-filled mitochondria, known as ring sideroblasts visualised by Prussian blue stain (Perl's reaction), is diagnostic of SA. ${ }^{10}$ Once acquired causes of SA are ruled out, molecular testing should be considered to look for congenital causes. ${ }^{11}$ The main management goals include correcting reversible causes or MDS, pyridoxine administration for responsive subtypes, thiamine supplementation for TRMA, iron chelation to prevent organ damage from iron overload and red cell transfusions for symptomatic anaemia.

We present the case of an African American man in his 20s with Sickle Cell Anaemia (SCA) who received chronic red cell count (RCC) exchange transfusions for ten years and became poorly responsive to transfusion with increased transfusion requirement. Bone marrow biopsy revealed increased erythropoiesis with 20\% ringed sideroblasts and normal cytogenetics and molecular analysis that led to diagnosis of a concomitant SA.

\section{CASE PRESENTATION}

An African-American man in his 20s with SCA (haemoglobin SS genotype) complicated by chronic thromboembolic pulmonary hypertension was receiving monthly RCC exchange transfusion for more than ten years and anticoagulation with apixaban. Postexchange transfusion, his haemoglobin ranged between 85 and $90 \mathrm{~g} / \mathrm{L}$ and $\mathrm{HbS}$ percentage measured 10\%-25\%. Deferasirox was prescribed for iron overload but he was poorly compliant. His 


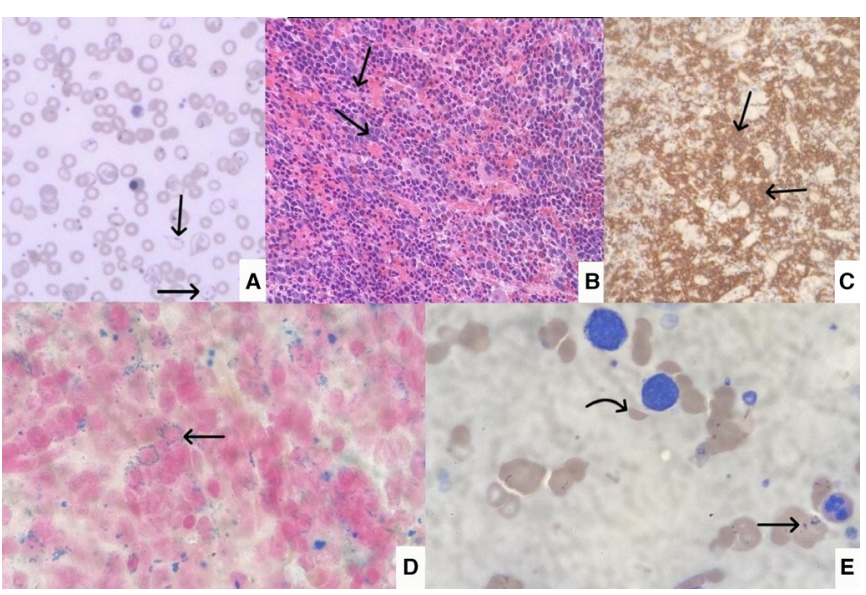

Figure 1 Peripheral blood smear and bone marrow smears from the patient with sideroblastic anaemia and sickle cell anaemia.

(A) Peripheral blood smear showing basophilic stippling and pappenheimer inclusions (arrows). (B) Bone marrow smear showing erythroid hyperplasia (arrows) on H\&E stain. (C) Bone marrow smear showing erythroid hyperplasia (arrows) on E-cadherin stain by immunohistochemistry. (D) Bone marrow smear showing Perl's reaction/ ring sideroblasts on iron stain (arrows). (E) Bone marrow smear showing sickle cells (curved arrow) and Pappenheimer bodies (straight arrow).

family history is significant for SCA in his sister, who succumbed to sudden death with pulmonary hypertension at age 21 . After 10 years of RCC exchange transfusions, the patient exhibited a consistent pattern of sharp decline in his haemoglobin 2 weeks after transfusion, from $85-90 \mathrm{~g} / \mathrm{L}$ to $50-60 \mathrm{~g} / \mathrm{L}$ at week 2 in the absence of bleeding.

\section{INVESTIGATIONS}

The initial concern was of alloimmunisation; however, his LDH was within normal limits, and the indirect Coombs test and extended alloantibody screen were repeatedly negative. Blood cultures from the vascular port sporadically grew Propionibacterium acnes on separate occasions. The vascular port was presumed to be colonised by bacteria and was removed. He received a month of penicillin antibiotic with subsequent negative blood cultures. Failure of the pattern of transfusion requirement to improve prompted additional workup.

Haemoglobin value was $98 \mathrm{~g} / \mathrm{L}$ immediately after transfusion; with labs 1 week post-transfusion revealing haemoglobin of 64 $\mathrm{g} / \mathrm{L}$, mean corpuscular volume $(\mathrm{MCV}) 80 \mathrm{fL}$, WCC $10.3 \times 10^{9} / \mathrm{L}$, absolute neutrophil count $1300 / \mathrm{mm}^{3}$, platelet count $177 \times 10^{9} / \mathrm{L}$, elevated ferritin of $>1000 \mu \mathrm{g} / \mathrm{L}$, reticulocyte count of $12 \%$ with retic index of 3.04, elevated erythropoietin level $1007 \mathrm{mIU} / \mathrm{mL}$ and normal LDH 215 units/L, slightly elevated bilirubin 2.7 $\mathrm{mg} / \mathrm{dL}(46.15 \mu \mathrm{mol} / \mathrm{L})$ and serum creatinine $0.88 \mathrm{mg} / \mathrm{dL}(77.7$ $\mu \mathrm{mol} / \mathrm{L})$. Peripheral smear showed few nucleated RCCs without polychromasia, marked coarse basophilic stippling, large Pappenheimer inclusion in the red cells and occasional dysplastic mononuclear white cells (figure 1A). Additional laboratory tests for anaemia including vitamin $\mathrm{B}_{12}$ was normal and Parvovirus B19 PCR, EBV IgM \& IgG, Babesia Microti IgG were negative (table 1).

Bone marrow biopsy showed increased erythropoiesis (figure $1 \mathrm{~B}, \mathrm{C}$ ) and Prussian Blue/ iron stain revealed markedly increased mitochondrial siderotic iron with staining of the Pappenheimer bodies and basophilic stippling of the nonnucleated red cells with $20 \%$ ringed sideroblasts consistent with
Table 1 Relevant lab and pathology

\begin{tabular}{|c|c|}
\hline $\begin{array}{l}\text { Labs post } 2 \text { weeks of exchange } \\
\text { transfusion }\end{array}$ & Result \\
\hline Haemoglobin (g/L) & 64 \\
\hline Haematocrit (\%) & 20.6 \\
\hline WCC $\left(\times 10^{9} / L\right)$ & 10.3 \\
\hline Platelet count $\left(\times 10^{9} / \mathrm{L}\right)$ & 177 \\
\hline Mean Corpuscular Volume (MCV) (fL) & 80 \\
\hline Reticulocyte count (\%) & 12 \\
\hline Absolute Reticulocyte Index & 3.04 \\
\hline $\begin{array}{l}\text { Lactate dehydrogenase (units/L) (N } \\
\text { 87-241) }\end{array}$ & 215 \\
\hline $\begin{array}{l}\text { Total bilirubin (mg/dL) (N 0.2-1.30) / } \\
(\mu \mathrm{mol} / \mathrm{L})(\mathrm{N} 3.41-22.2)\end{array}$ & $2.7 / 46.15$ \\
\hline \multicolumn{2}{|l|}{ Additional workup: } \\
\hline Ferritin $(\mu \mathrm{g} / \mathrm{L})$ & $\begin{array}{l}1993 \text {-->794 (improved with iron chelation within } \\
6 \text { months) }\end{array}$ \\
\hline Serum immunofixation (IFE) & No monoclonal protein \\
\hline Epstein-Barr Virus (EBV) Ab & $<10$ \\
\hline HIV & Non-reactive \\
\hline Parvovirus B19 PCR & Not detected \\
\hline Babesia microti IgG & $<1: 16$ \\
\hline $\begin{array}{l}\text { Vitamin } B_{12} \text { level }(\mathrm{pg} / \mathrm{mL})(\mathrm{n}=232-1245) \\
/ \mathrm{pmol} / \mathrm{L}(\mathrm{n}=171.1-918)\end{array}$ & $595 / 438.99$ \\
\hline $\begin{array}{l}\text { Folate level }(\mathrm{ng} / \mathrm{mL})(\mathrm{N}=>3) / \mathrm{nmol} / \mathrm{L} \\
(\mathrm{n}>6.81)\end{array}$ & $10 / 22.72$ \\
\hline $\begin{array}{l}\text { Vitamin } B_{6} \text { level }(\mu \mathrm{g} / \mathrm{L})(n=5.3-46.7) / \\
\mathrm{nmol} / \mathrm{L}(\mathrm{n}=214.4-1889.5)\end{array}$ & $\begin{array}{l}2.1 / 84.9 \text {-->35.5/1436 (improved with B6 } \\
\text { supplementation in } 6 \text { months) }\end{array}$ \\
\hline $\begin{array}{l}\text { Copper level (ug/mL) }(n=0.5-1.5) / \\
\mu \mathrm{mol} / \mathrm{L}(\mathrm{n}=7.86-23.6)\end{array}$ & $1.3 / 20.45$ \\
\hline Lead level & Nil \\
\hline $\begin{array}{l}\text { Erythropoietin level }(\mathrm{mIU} / \mathrm{mL}) \\
(\mathrm{n}=2.6-18.5)\end{array}$ & 1007 \\
\hline Peripheral smear & $\begin{array}{l}\text { Increase \% of nucleated RCCs without } \\
\text { polychromasia, marked basophilic stippling and } \\
\text { large Pappenheimer inclusion in the red cells }\end{array}$ \\
\hline Bone marrow biopsy: & $\begin{array}{l}\text { Increased erythropoiesis with increased stainable } \\
\text { storage and siderotic iron with ring sideroblasts } \\
\text { consistent with sideroblastic anaemia (figure 1) }\end{array}$ \\
\hline FISH, MDS/myeloid panel & $\begin{array}{l}-5 / 5 q-,-7 / 7 q-,+8,20 q-\text { negative (No } \\
\text { chromosomal deletions or translocations, normal } \\
\text { karyotype) }\end{array}$ \\
\hline Genetic testing: & $\begin{array}{l}\text { ALAS2 negative (X linked sideroblastic anaemia } \\
\text { (XLSA) in males) } \\
\text { ABCB7 negative (XLSA and ataxia (XLSA/A)) } \\
\text { SLC1125A38, GLRX5 negative (autosomal } \\
\text { recessive congenital sideroblastic anaemia) } \\
\text { TRNT1 negative (sideroblastic anaemia with } \\
\text { B cell immunodeficiency, periodic fevers and } \\
\text { developmental delay) } \\
\text { SLC19A2 negative (thiamine-responsive } \\
\text { megaloblastic anaemia), } \\
\text { MITO, PUS1 negative (myopathy, lactic acidosis } \\
\text { and sideroblastic anaemia (MLASA) and MLASA } \\
\text { variants) } \\
\text { YARS2 heterozygous and with no clinical } \\
\text { correlation (MLASA variant) } \\
\text { Protein variant effect analyzer - no biological } \\
\text { function of protein) }\end{array}$ \\
\hline
\end{tabular}

FISH, fluorescent in situ hybridisation; MDS, myelodysplastic syndromes; RCC, red cell count; WCC, white cell count.

SA (figure 1D,E). Subsequent workup to determine the cause of SA included slightly low serum pyridoxine (B) levels at $2.1 \mu \mathrm{g} / \mathrm{L}$ (normal=5.3-46.7) or $84.9 \mathrm{nmol} / \mathrm{L}$ (normal=214.4-1889.5) and normal serum copper, lead levels and urine aminolevulinic acid levels (table 1). Fluorescent in situ hybridisation MDS panel did not reveal chromosomal deletions or translocations and karyotype was normal (negative for deletions of $5 \mathrm{q}, 7 \mathrm{q}$ and $20 \mathrm{q}$; 
monosomies chromosome 5 and 7; and trisomy of chromosome 8). Next-generation sequencing (NGS) failed to identify any karyotypic or molecular abnormalities suggestive of MDS/MPN related SA, including SF3B1 and JAK2 gene mutations. Genetic testing for congenital mutations, including ALAS2/XLSA and mitochondrial mutations such as SLC1125A38, SLC19A2, TRNT1, ABCB7, GLRX5, MITO, PUS1 were not detected. ${ }^{11}$ YARS2 mutation was identified with no clinical significance ascribed to heterozygosity.

\section{TREATMENT}

The patient was started on pyridoxine to a maximal dose of 500 mg daily for over 6 months with no improvement in the pattern of the anaemia despite the normalisation of the serum $\mathrm{B}_{6}$ levels $(35.5 \mathrm{ug} / \mathrm{L})$. Iron chelation with deferasirox led to decline in the serum ferritin to $<1000 \mu \mathrm{g} / \mathrm{L}$. However, the patient continued to require RCC transfusions every 2 weeks. Peripheral blood smear continued to show coarse basophilic stippling and large clusters of Pappenheimer bodies.

\section{OUTCOME AND FOLLOW-UP}

The patient was referred for allogeneic stem cell transplantation and is currently in process of finding a suitable donor.

\section{DISCUSSION}

The case highlights the diagnostic challenge of severe anaemia in a patient with SCA and transfusion dependency in the absence of increased haemolysis. Worsening anaemia in a patient receiving chronic transfusion for SCD has a broad differential diagnosis, including vitamin and iron deficiencies, delayed haemolytic transfusion reactions, viral infections including parvovirus, epstein-barr virus (EBV), HIV, bacterial infections including streptococcus pneumoniae, salmonella, other streptococci ${ }^{12-14}$ and other bone marrow failure syndromes. Elevated serum ferritin, and increased erythropoiesis with stainable storage and siderotic iron with a high percentage of ringed sideroblasts $(20 \%)$ on bone marrow biopsy confirmed the diagnosis of SA. ${ }^{10}$

To the best of our knowledge, there have been no previous reports of SCA and concomitant SA. Acquired causes of SA are more common in adults and are investigated first. In our patient, toxic exposures to alcohol, lead or copper deficiency were ruled out. Vitamin $\mathrm{B}_{6}$ deficiency can cause SA, however; typical bone marrow findings, as in this case, would not be present. ${ }^{10} 15$ These acquired causes of SA interfering with heme synthesis are usually reversible. ${ }^{16}$ Our patient did not respond to pyridoxine replacement. In acquired clonal causes such as MPN/MDS, somatic mutations lead to a clonal expansion of haematopoietic stem, progenitor and mature cells. MDS/MPN-related mutations such as SF3B1 mutation (occurs in 70\%-90\% of MDS-related SA), JAK2 (usually occurs in MDS with thrombocytosis subtype) and congenital mutations such as XLSA (ALAS2) were not detected in our patient. Other reasons that make MDS/MPN less likely include age than 40 and absence of evidence of dysplasia or clonal haematopoiesis on flow cytometry and BM biopsy. CSArelated genetic mutations were negative in our case (table 1). SA in our case was diagnosed as idiopathic versus due to unknown underlying mutation. Despite expanding knowledge on mutation and inheritance patterns in SA, a subset of SA patients remain with no identifiable genetic defect and are classified as idiopathic similar to our case. ${ }^{17} 18$

The definitive treatment of SA is unknown; MPN/MDS and CSA have genetic pathogenesis, which can be treated but not curable. ${ }^{16}$ There are few case reports of allogeneic stem cell transplantation considered for CSA. ${ }^{19} 20$ Allogeneic haematopoietic stem cell therapy is a curative therapy for SCD. In our patient with concomitant refractory idiopathic SA, we, therefore, consider stem cell transplant evaluation the potential next step of management. ${ }^{21} 22$

The case also highlights the potential for missed diagnosis due to anchoring bias based on the notion that SCD was the sole cause of anaemia, leading to premature closure and delayed diagnosis of SA. Anchoring bias is a cognitive bias where an individual relies too heavily on the initial diagnosis to draw conclusions and make decisions, despite evidence pointing to the contrary. ${ }^{23}$ Premature closure bias is the tendency to accept a diagnosis before it has been fully verified..$^{23}$ As highlighted in our case, these cognitive biases make clinicians susceptible to missing the possibility of alternative diagnosis in a pre-established cause.

There are a few limitations of this case study, including that, our workup did not reveal any known acquired or congenital mutations previously associated to SA. Several mutations such as FECH, HSPA9 and HSCB (associated with ARCSA), NDUFB11 (associated with XLSA) and LARS2 and MT-ATP6 (associated with MLASA and MLASA variants) were not included in the standard NGS panel in our institute and were not tested in this patient. ${ }^{16}$ Additionally, concurrent SCA with transfusion history posed a challenge to narrow the differential diagnosis of SA based on MCV. SA when microcytic could point towards isoniazid, XLSA in males, XLSA and ataxia (XLSA/A), ARCSA, SIFD as the cause of SA. Normocytic/macrocytic SA occurs in alcoholism, copper deficiency, MLASA, TRMA, MDS with ring sideroblasts and dysplasia subtypes. ${ }^{11} \mathrm{MCV}$ is irrelevant in our case due to frequent transfusion history.

In conclusion, this case highlights the rare occurrence of SCA and SA in a patient. This case also underscores the importance of generating a broad differential diagnosis and the ramifications of anchoring bias which can lead to delayed diagnosis. While this patient's presentation of anaemia with an increased need for red cell transfusion was thought to be due to SCD, workup revealed

\section{Learning points}

- Due to its low prevalence, the diagnosis of sideroblastic anaemias (SA) is often difficult. High suspicion on the part of the clinician and low threshold for workup of anaemia often aid in the diagnosis of SA.

- Loss of response to a previously effective long-term treatment of anaemia should raise suspicion of an additional cause of anaemia.

- A full workup, including peripheral smear, complete blood count with differential, iron studies, ferritin and reticulocyte count, is warranted when SA is suspected. A bone marrow biopsy is required to confirm the diagnosis, and genetic testing should be done if congenital SA is suspected.

- Workup to identify the cause of SA includes ruling out secondary and acquired causes, genetic testing in the appropriate population and identify myelodysplastic syndromes (MDS)/myeloproliferative neoplasms-related underlying mutations.

- Acquired causes of SA such as copper deficiency, pyridoxine deficiency and medication-related are often reversible. In contrast, SA secondary to MDS and congenital SA have a genetic basis and are potentially treatable but not curable. Early diagnosis and treatment initiation help improve the anaemia and prevent long-term complications. 
a much less common diagnosis of SA. SA is rare in the general population, ${ }^{5}$ and when coupled with anchoring bias related to a well-known cause of anaemia such as SCD can lead to delay in diagnosis. This case highlights the importance of avoiding premature closure when managing common diseases and calls on the clinician to ask, 'What else could it be?'

Acknowledgements Dr Jayashree Ramskrishnan, a pathologist at our institute has provided us with knowledge on histopathological analysis.

Contributors NV and MC were involved in the literature search and writing the manuscript. IMS-C involved in writing and review of the manuscript. HPS was involved in the idea, supervision and review of the manuscript. All authors reviewed the final manuscript.

Funding The authors have not declared a specific grant for this research from any funding agency in the public, commercial or not-for-profit sectors.

\section{Competing interests None declared.}

Patient consent for publication Consent obtained directly from patient(s). Provenance and peer review Not commissioned; externally peer reviewed.

Open access This is an open access article distributed in accordance with the Creative Commons Attribution Non Commercial (CC BY-NC 4.0) license, which permits others to distribute, remix, adapt, build upon this work non-commercially, and license their derivative works on different terms, provided the original work is properly cited and the use is non-commercial. See: http://creativecommons.org/ licenses/by-nc/4.0/.

Case reports provide a valuable learning resource for the scientific community and can indicate areas of interest for future research. They should not be used in isolation to guide treatment choices or public health policy.

\section{ORCID iD}

Nikitha Vobugari http://orcid.org/0000-0001-7622-0219

\section{REFERENCES}

1 Pace BS, Ofori-Acquah SF, Peterson KR. Sickle cell disease: genetics, cellular and molecular mechanisms, and therapies. Anemia 2012;2012:143594.

2 Okam MM, Shaykevich S, Ebert BL, et al. National trends in hospitalizations for sickle cell disease in the United States following the FDA approval of hydroxyurea, 19982008. Med Care 2014;52:612-8.

3 Payne AB, Mehal JM, Chapman C, et al. Trends in sickle cell disease-related mortality in the United States, 1979 to 2017. Ann Emerg Med 2020;76:S28-36.
4 Ashorobi D, Chhabra A. Sideroblastic anemia. In: StatPearls [Internet]. StatPearls Publishing, 2020. https://www.ncbi.nlm.nih.gov/books/NBK538287/

5 Brissot P, Bernard DG, Brissot E, et al. Rare anemias due to genetic iron metabolism defects. Mutat Res Rev Mutat Res 2018;777:52-63.

6 Fujiwara T, Harigae H. Pathophysiology and genetic mutations in congenital sideroblastic anemia. Pediatr Int 2013;55:675-9.

7 Furuyama K, Kaneko K. Iron metabolism in erythroid cells and patients with congenital sideroblastic anemia. Int J Hematol 2018;107:44-54.

8 Arber DA, Orazi A, Hasserjian R, et al. The 2016 revision to the World Health Organization classification of myeloid neoplasms and acute leukemia. Blood 2016;127:2391-405.

9 Camaschella C. Hereditary sideroblastic anemias: pathophysiology, diagnosis, and treatment. Semin Hematol 2009;46:371-7.

10 Cazzola M, Invernizzi R. Ring sideroblasts and sideroblastic anemias. Haematologica 2011;96:789-92

11 Ducamp S, Fleming MD. The molecular genetics of sideroblastic anemia. Blood 2019;133:59-69.

12 Booth C, Inusa B, Obaro SK. Infection in sickle cell disease: a review. Int J Infect Dis 2010;14:e2-12.

13 Vichinsky E, Kleman K, Embury S, et al. The diagnosis of iron deficiency anemia in sickle cell disease. Blood 1981;58:963-8.

14 Sherwood JB, Goldwasser E, Chilcote R, et al. Sickle cell anemia patients have low erythropoietin levels for their degree of anemia. Blood 1986;67:46-9.

15 Narang NC, Kotru M, Rao K, et al. Megaloblastic anemia with ring sideroblasts is not always myelodysplastic syndrome. Tjh 2016;33:358-9.

16 Abu-Zeinah G, DeSancho MT. Understanding sideroblastic anemia: an overview of genetics, epidemiology, pathophysiology and current therapeutic options. J Blood Med 2020;11:305-18

17 Bergmann AK, Campagna DR, McLoughlin EM, et al. Systematic molecular genetic analysis of congenital sideroblastic anemia: evidence for genetic heterogeneity and identification of novel mutations. Pediatr Blood Cancer 2010;54:273-8.

18 Liu G, Guo S, Kang H, et al. Mutation spectrum in Chinese patients affected by congenital sideroblastic anemia and a search for a genotype-phenotype relationship. Haematologica 2013;98:e158-60.

19 Kim MH, Shah S, Bottomley SS, et al. Reduced-toxicity allogeneic hematopoietic stem cell transplantation in congenital sideroblastic anemia. Clin Case Rep 2018;6:1841-4.

20 Ayas M, Al-Jefri A, Mustafa MM, et al. Congenital sideroblastic anaemia successfully treated using allogeneic stem cell transplantation. Br J Haematol 2001;113:938-9.

21 Shenoy S. Hematopoietic stem-cell transplantation for sickle cell disease: current evidence and opinions. Ther Adv Hematol 2013;4:335-44.

22 Bauer DE, Brendel C, Fitzhugh CD. Curative approaches for sickle cell disease: a review of allogeneic and autologous strategies. Blood Cells Mol Dis 2017;67:155-68.

23 Saposnik G, Redelmeier D, Ruff CC, et al. Cognitive biases associated with medical decisions: a systematic review. BMC Med Inform Decis Mak 2016;16:138.

Copyright 2022 BMJ Publishing Group. All rights reserved. For permission to reuse any of this content visit

https://www.bmj.com/company/products-services/rights-and-licensing/permissions/

BMJ Case Report Fellows may re-use this article for personal use and teaching without any further permission.

Become a Fellow of BMJ Case Reports today and you can:

- Submit as many cases as you like

- Enjoy fast sympathetic peer review and rapid publication of accepted articles

- Access all the published articles

- Re-use any of the published material for personal use and teaching without further permission

Customer Service

If you have any further queries about your subscription, please contact our customer services team on +44 (0) 2071111105 or via email at support@bmj.com.

Visit casereports.bmj.com for more articles like this and to become a Fellow 